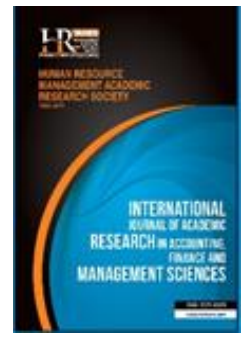

International Journal of Academic Research in Accounting, Finance and Management Sciences

Vol. 8, No.2, April 2018, pp. 48-64

E-ISSN: 2225-8329, P-ISSN: 2308-0337

(C) 2018 HRMARS

www.hrmars.com

To cite this article: Alamri, A.M. (2018). Strategic Management Accounting and the Dimensions of Competitive Advantage: Testing the Associations in Saudi Industrial Sector, International Journal of Academic Research in Accounting, Finance and Management Sciences 8 (2): 48-64.

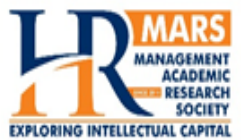

http://dx.doi.org/10.6007/IJARAFMS/v8-i2/4137 (DOI: 10.6007/IJARAFMS/v8-i2/4137)

\title{
Strategic Management Accounting and the Dimensions of Competitive Advantage: Testing the Associations in Saudi Industrial Sector
}

\author{
Ahmad Mohammed ALAMRI \\ King Saud University-Saudi Arabia, E-mail: ahamri@ksu.edu.sa
}

\begin{abstract}
In the last decade, many dramatic changes in the organizations' environment have led to fundamental transformations in the framework of management accounting practices; specifically the shift toward practicing its functions and tasks from a strategic approach. This exploratory study examines the impact of strategic management accounting on the dimensions of competitive advantage. Using data from 289 management accountants and 289 senior managers working at Saudi industrial companies located in Riyadh industrial cities, the present study finds that practicing management accounting from a strategic perspective significantly affects the dimensions of competitive advantage (i.e. cost, quality, flexibility and delivery). In the context of its proposed model, the present study supports that Saudi industrial companies can enhance their ability to achieve competitive advantage through practicing of strategic management accounting in terms of the adoption and use of strategic management accounting techniques and the involvement of management accountants in strategic management processes.

Key words

Strategic Management Accounting, Competitive Advantage, Industrial Sector, Saudi Arabia

Received: 14 Apr $2018 \quad$ (c) The Authors 2018

Revised: 30 Apr $2018 \quad$ Published by Human Resource Management Academic Research Society (www.hrmars.com)

Accepted: 15 May 2018 This article is published under the Creative Commons Attribution (CC BY 4.0) license. Anyone may reproduce, distribute, translate and create derivative works of this article (for both commercial and noncommercial purposes), subject to full attribution to the original publication and authors. The full terms of this license may be seen at: http://creativecommons.org/licences/by/4.0/legalcode
\end{abstract}

\section{Introduction}

Over the past two decades, the business environment has undergone successive changes as a result of the tremendous reliance on information systems and modern communications, in addition to the openness in the global market. These changes have resulted in increasing pressures on companies to be more competitive, and shifting their attentions to maximize efficiency in exploiting resources in order to control markets or maintain their competitive positions. Therefore, traditional management practices are no longer sufficient for organizational growth and survive. Moreover, contemporary companies need accurate and reliable information to make appropriate decisions regarding the environmental factors surrounding them.

In the current millennium, management accounting has become one of the vital nerves for the decision-making process in contemporary companies; because of its strategic role in providing useful and significant information to the top management in order to cope with the dynamic environment, and to run the company in effective, efficient, and economic manners. Therefore, practicing management accounting from a strategic approach (labeled as Strategic Management Accounting) (Mia and Clarke, 1999; Noordin et al., 2015) is mainly an effective way for providing contemporary companies with the information required for strategic decision making process (Roslender and Hart, 2002; Ah Lay and Jusoh, 2011), gaining competitive advantages, and improving future-oriented performance (Johnson and Kaplan, 1987; Ahid and 
Augustine, 2012). However, shifting toward the strategic approach in management accounting practices is partially based on the ground that this approach can show the reflection and correlation between strategic management methods and the information that the accountants seek to provide (Bromwich, 1990; Johnson and Kaplan, 1987).

The focus of strategic management accounting is on the external and market- oriented information rather than historical and internal information (Cadez and Guilding, 2012). Accordingly, strategic management accounting is directed toward major elements of the company's external environment such as market positioning, product, competitors, suppliers and customers (Kırlı and Gümüş, 2011). Additionally, in the light of strategic management accounting, company strategy represents a contextual factor that shapes the nature of management accounting practices, and therefore, enhancing the company capabilities in gaining competitive advantage (Roslender and Hart, 2002). Moreover, strategic management accounting can help in creating strategic value through effective and efficient use of resources (Chenhall and LangfieldSmith, 1998), directing and controlling the operational activities, measuring the performance at all organizational levels, and estimating the company's competitive position (Hilton, 2008).

In the light of the relationship between strategic management accounting and competitive advantage, the empirical studies that support this relationship have been still scant despite the conceptualized positive relationship between these two constructs. To date, the field of strategic accounting management suffers from a lack of empirical investigation (Nixon and Bums, 2012). Past empirical work has focused in investigating the relationship between strategic management accounting and financial performance, nonfinancial performance, decision-making process and business strategy (e.g. AlKhadash and Feridun, 2006; Ah Lay and Jusoh, 2011; Chenhall and Langfield-Smith, 1998; Cadez and Guilding, 2012; Hammad et al., 2010). In business Arab environment, particularly in Saudi Arabia, it is noticeable that there is no one piece of empirical research dealing with strategic management accounting. To sum up, there is a gap in our current understanding of the influence of strategic management accounting on gaining competitive advantages. The lack of empirical evidence regarding this influence can make contemporary companies in developed and developing countries less aware about the role of strategic management accounting on enhancing their companies' outcomes such as gaining competitive advantages. To help in addressing this gap, the objective of the current study is primarily to examine the impact of strategic management accounting on the main dimensions of competitive advantage. Therefore, the current study contributes to the research scope in the fields of strategic management accounting and competitive advantages in order to further expansion of our current understanding of the role of strategic management accounting in gaining competitive advantages in companies.

The industrial sector in the Kingdom of Saudi Arabia has witnessed a steady development which has achieved many remarkable achievements. This is due to the interest and support from the Saudi government, in view of the role this sector plays in achieving the strategic and economic objectives of the Kingdom. The support from Saudi government includes several main aspects such as the provision of necessary infrastructure, the establishment of industrial cities in different regions of the Kingdom, the establishment of the Saudi Industrial Development Fund, and the provision of a number of other industrial incentives. The industrial base in the Kingdom has witnessed a significant expansion over the last four decades. The number of industrial companies jumped from $(206)$ in 1974 to $(7,741)$ in 2016. In parallel, the invested capital increased from SR 4.3 billions in 1974 to SR 1.1 trillion in 2016. The number of workers also increased from about (10) thousand workers in 1974 to more than one million workers in 2016. Industrial production in the Kingdom has grown significantly over the past period. GDP at constant prices of manufacturing industries rose from SR 32 billion in 1974 to SR 310 billion at the end of 2016. In addition, the growth rate of the industrial sector continued to rise throughout this period. The average annual growth of the real GDP of manufacturing industries during this period was about $5.6 \%$, one of the highest growth rates among the other economic sectors and the most sustainable (Saudi Industrial Development Fund, 2018).

As this industrial sector is one of the largest sectors in the Kingdom and most companies of this sector need to adapt and implement a strategic approach of management accounting to enhance their role, this sector has been selected for conducting this study. In particular, this study addresses the following question: "Does strategic management accounting significantly influence the dimensions of competitive 
advantage in Saudi industrial sector?" The present study is an attempt to bridge the gap in addressing the role of strategic management accounting in gaining competitive advantages. Hopefully, this may contribute in drawing managers' attention in industrial companies about the importance of this vital issue, and implementing it on scientific and applied principles as a means for achieving competitive advantages.

\section{Literature Review and Theoretical Framework}

\subsection{Strategic Management Accounting}

Simmonds (1981) was the first author who introduced the concept of strategic management accounting in management accounting literature. He defined strategic management accounting as "the provision and analysis of management accounting data about a business and its competitors used for developing and monitoring business strategy". In the same vein, Bromwich (1990) defined this concept as "the provision and analysis of financial information on the firm's product markets and competitors' costs and costs structures and the monitoring of the enterprise's strategies and those of its competitors in these markets over a number of periods". These two early definitions of strategic management accounting indicate explicitly for the potential role of strategic management accounting in sustaining competitive advantages by providing decision makers with financial information needed to identify the competitive position of the organization. Several definitions that followed Simmonds (1981) and Bromwich (1990) try to orient strategic management accounting with strategic management and marketing function. For example, Roslender and Hart (2003) define strategic management accounting "as a generic approach to accounting for strategic positioning, defined by an attempt to integrate insights from management accounting and marketing management within a strategic management framework". In addition, some authors (e.g. Agasisti et al. 2008; Langfield-Smith, 2008; Ma and Tayles, 2009; Tillmann and Goddard, 2008; Roslender and Hart, 2010) have considered strategic management accounting as a new stream that orients management accounting system with the strategic direction of organization. In this view, strategic management accounting is oriented toward the facets of strategic management, which encompass formulation, implementation, and controlling. For example, a recent study has found that strategic management accounting is an important antecedent in the context of strategic planning (Cuganesan et al., 2012).

However, there is no consensus between researchers and authors regarding the definition of strategic management accounting. Instead, they almost agree that the definition of strategic management accounting must not limit its role to the provision of specific type of information (e.g. competitors) instead of having multifaceted information (e.g. competitors, customers, market, products, general environment, etc.) (Carlsson-Wall et al., 2015; McManus, 2013). In fact, this multifaceted information can make a considerable contribution in term of bridging the strategic management literature and management accounting into a unified strategic management framework. Some researchers and authors try to express this way of bridging into their definition of strategic management accounting. For example, Hoque (2001) defined strategic management accounting as "a process of identifying, gathering, choosing and analyzing accounting data for helping the management team to make strategic decisions and to assess organizational effectiveness". Furthermore, The Chartered Institute of Management Accountants' official terminology defines strategic management accounting as "a form of management accounting in which emphasis is placed on information which relates to factors external to the entity, as well as non-financial information and internally generated information" (Jack, 2009). Therefore, strategic management accounting is a contemporary approach of accounting organized around the strategic orientation of organization as an attempt to develop and monitor of organization strategy and for control activities purposes. According to Soltani et al. (2014), researchers in the field of competitive advantages indicate that organizations need strategic management accounting in order to improve their performance since they face changing competitive conditions by providing the managers with the needed information.

However, the main question in this context is how to integrate the strategic management accounting with the strategic management in organization? In order to answer this question, Cadez and Guilding (2008) have conceptualized and operationalized strategic management accounting as a two major dimensions. These are (1) the adoption and use of strategic management accounting techniques and (2) management accountant's involvement in strategic management processes. Later, most empirical work 
have used these two dimensions as indicators for practicing strategic management accounting in organization (Ah Lay and Jusoh, 2011; Aksoylu and Aykan, 2013; Dunk, 2011; Oboh and Aljibolade, 2017; Tillmann and Godddard, 2008).

In the light of the first dimension of strategic management accounting that is the adoption of strategic management accounting techniques, these techniques were categorized into main five practices as follow:

(1) Costing: six techniques were comprised into this practice to determine, analyze, and manage costs in a strategic manner. These techniques are: activity-based costing, attribute costing, life cycle costing, quality costing, target costing, and value chain costing. They represent an important element in an external and forward-looking orientation, and the development of strategies (Cuganesan et al., 2012; Ewert and Ernst, 1999; Roslender and Hart, 2010).

(2) Planning, control, and performance measurement: benchmarking and integrated performance measurements (e.g. balanced scorecard) are the main techniques that related to this category. In implementing benchmarking with its external and forward-looking orientation, company is searching for best practices of competitors as a means for enhancing its performance and strategic positioning (Cadez and Guilding, 2008; Cinquini and Tenucci, 2010). However, in implementing integrated performance measurements with their internal and external perspectives, companies can use both financial and nonfinancial performance measures. For example, balanced scorecard assumes an internal and external orientation paralleled with forward-looking orientation (Kaplan and Norton, 2001). Accordingly, these techniques can lend a helping hand for managers in developing, implementing, and controlling of strategies and identifying and managing of the intellectual capital (Tayles et al., 2007).

(3) Strategic decision-making: this practice comprises three effective techniques about the strategic orientation of the company. These techniques are strategic costing, strategic pricing and brand valuation. All of these techniques confer external and forward-looking orientations (competitors, market, products, etc) and allow creating and achieving competitive advantages (Roslender and Hart, 2010).

(4) Competitor accounting: this practice includes: competitor cost assessment, competitor appraisal performance and competitive position monitoring (Shah et al., 2011). Their external orientations make these techniques useful in the strategic decision-making process including strategy formulation and strategy monitoring (Cinquini and Tenucci, 2010).

(5) Customer accounting: this practice focuses on customers and comprises customer profitability/cost analysis, lifetime customer profitability analysis and valuation of customers as assets. As other previous practices, these three techniques confer an external and forward-looking orientation. In sum, these techniques allow assessing the profitable relationships with customers, improving the formulation of strategies related with the 4Ps of marketing (product, pricing, promotion and place), and supporting the utilization of resources related to customers. Accordingly, these techniques can enhance the integration or fit among the strategic management, management accounting and marketing (Andon and Baxter, 2011).

As noted from the above-mentioned practices, the main criterion for considering the management accounting technique as a strategic one is the external orientation of the technique and its ability to provide future information (forward-looking orientation). According to Carlsson-Wall et al. (2015) and McManus (2013), the information provided by these techniques is essential in the formulation and monitoring of strategy and for sustainable value creation.

The second dimension of conceptualizing and operationalizing strategic management accounting is the management accountant's involvement in strategic management processes. The importance of this involvement or participation is identified in term of management accountant's role in developing of strategic management accounting system and in enhancing several organizational functions (Cadez and Guilding, 2008; Chiucchi, 2013; Tillmann and Goddard, 2008). Cadez and Guilding (2008) and Siegel and Sorensen (1999) suggest that management accountants should enhance their proactive role in the strategic management process by developing their financial and managerial accounting knowledge, analytical, verbal and written skills, and working within a team. Furthermore, management accountants should also work in an integrated manner with other organizational units to achieve a high degree of synergy (Oboh and Aljibolade, 2017). This can be done by formulating effective cross-functional team from various 
departments of the organization (Aver and Cadez, 2009) that is equipped with necessary information literacy skills for identifying, utilizing, evaluating and interpreting information (Mishra and Mishra, 2010). According to Fauré and Rouleau (2011), management accountants have the key skills that are essential to promote changes needed in the light of dynamic environment. Accordingly, those accountants can support the company to take the best decisions for its strategic alternatives in a transparent and objective way (Tillmann and Goddard, 2008). With regard to management accountants' role, Nixon and Burns (2012) stated that:

"A further advantage that accountants enjoy is that their financial assessments of marketing, operations, or new product design and development decisions are likely to be perceived by senior management as relatively more objective than those of discipline managers directly concerned."

The active role of management accountant was also identified in Simmonds (1982) suggestions. He claimed that the anticipation of competitors' actions and reactions heavily depends on the involvement of management accountant in external information provision. In addition, Bromwich and Bhimani (1994) stated that:

"Strategic management accounting requires that accountants embrace new skills extending beyond their usual areas and cooperate much more with general management, corporate strategists, marketing and product development"

According to Brouthers's and Roozen (1999) study, the gap between traditional management accounting and strategic management can be filled by the management accountant involvement in strategic decision making process which in turn helps senior managers to make informed, timely decisions. Moreover, this role of management accountant is recently extended to be a strategic partner to support the strategic orientation of organization (Ahid and Augustine, 2012). Therefore, the role of management accountant should change dramatically from being a source of information to a business strategic partner and advisor. This requires that a management accountant must have good interdisciplinary knowledge and analytic, financial, and decision-making skills (Tillmann and Goddard, 2008). In addition to their financial orientation, management accountants must adopt more non-financial orientation. This means that information about the external and internal contexts, customers, competitors, products, and markets must be the core emphasis of their work (McManus and Guilding, 2008). Several recent studies have shown that the role of management accountants has changed to be a strategic role rather than a bean-counter (Chiucchi, 2013; Fauré and Rouleau, 2011; Hiller et al., 2014; Lambert and Pezet, 2011).

\subsection{Dimensions of Competitive Advantage}

In general, the concept of competitive advantage refers to the ability of the company to formulate and implement strategies that make it in a better position than competitors through better utilization of the technical, physical, financial and organizational capabilities and resources that enable it to design and implement its competitive strategies. However, the achievement of competitive advantage is linked to two main dimensions: the perceived value of the customer and the ability of the company to achieve excellence (Weinstein, 2012).

The importance of the competitive advantage lies in the fact that it gives companies the ability to defend their market position and maintain their competitive position among their competitors, in addition to enhancing the company's capabilities and production and marketing skills, and strengthening customer relations and improving decisions (Sigalas et al., 2013). Kotler (1997) defined competitive advantage as "an organizational capability to perform in one or many ways that competitors find difficult to reproduce now and in the future". Anik et al. (2010) considers competitive advantage as the ability of company to meet the needs of customers and satisfy them, as well as to meet the needs of employees in the company, and to achieve a higher return on investment for growth, in addition to developing and reaching its goals and objectives. It is also a group of factors that have a direct and indirect relationship to the stability of the company in the market (Baroto et al., 2012). Nyalika and Namusonge (2015) believe that competitive advantage is the most appropriate tool for discovering new, creative and innovative ways to produce and deliver goods and services more effectively than competitors in the market. In addition, Ranjith (2016) believes that competitive advantage is a strategy that develops the company's business model, accelerates its growth and development, and provides the company with the opportunity to produce and deliver 
services, goods and benefits to its customers that outperform its competitors and improving its reputation in the market. From the above discussion and definitions, competitive advantage can be viewed as a set of factors or dimensions that enable company to outperform its competitors by meeting the requirements and needs of its external and internal customers, which in turn affects its market stability, market share, profitability, reputation etc.

In the past decades, Porter (1985) identified two common dimensions of competitive advantage. These are cost advantages (e.g. operating with lower cost compared to competitors) and differentiation advantages (e.g. differentiating by providing superior services, innovative methods, strong brand etc.). Later, this framework has expanded to include additional dimensions to conceptualize competitive advantage. In reviewing the related literatures in this area of concern, the researcher of the present study finds that there is a general agreement between authors and researchers regarding the basic dimensions of competitive advantage (see Brem et al., 2016; Diab, 2014). These dimensions are cost, quality, flexibility, delivery and innovation.

(1) Cost dimension: Baroto et al. (2012) emphasizes that any company must focus on cost to make the production and marketing costs of its products lower than those of its competitors. This lower cost enables company to acquire a higher market share as the basis for its success and superiority. According to Ranjith (2016), the lowest cost is the main operational objective of companies that compete through cost and even companies that compete through other non-cost competitive advantages. From economic and financial perspective, reducing the price of products contributes to create and increase demand as well as reduce the profit margin if the company does not produce its products at low costs (Sachitra et al., 2016). In addition, reducing costs can be achieved through the efficient use of its production capacity as well as continuous improvement of product quality and innovation in product design and process technology (Baroto et al., 2012). This is an important foundation for cost reduction as well as helping managers to support the strategy of the company to be a leader in the field of cost.

(2) Quality dimension: Wang et al. (2011) confirm that the company's expected value, which is commensurate with its mission, requires company to identify customers' expectations and desires for quality and work towards achieving them. According to Ware (2014), quality is an important competitive advantage, which refers to the performance of things correctly to provide products that fit the needs of customers. Thus, companies that do not provide quality products that meet the needs and desires of customers and their expectations cannot survive and succeed or eventually stay in competition. Daru (2016) agrees that the quality dimension of competitive advantage means the company's ability to deliver products that match the needs and desires of customers. Chen et al. (2013) assert that high quality products contribute to improving the company's reputation and customer satisfaction, and the company can impose higher prices if delivering high quality products to meet customer requirements.

(3) Flexibility dimension: Wang et al. (2011) describes flexibility as a rapid responding to changes that may occur in product design to suit customers' needs, whereas Combe (2012) describes it as the ability to quickly produce a wide range of products, introduce new products, modify existing products as a response to customer needs. Flexibility is also described as the ability of the company to change processes to other methods (e.g. changing the performance of operations and the way and time of performance of operations) (Eryesil et al., 2015). This change in processes includes four types of flexibility (Eryesil et al., 2015): (1) Product flexibility: means the ability of processes to deliver new or modified products; (2) Product-Mix flexibility: means the ability of processes to produce a mix of products; (3) Size Flexibility: refers to means the ability of processes to change the level of output or the level of production activity to provide different sizes of products; and (4) Delivery flexibility: refers to the ability of processes to change delivery times of products.

(4) Delivery dimension: Daniel et al. (2011) argue that delivery represents the base of competitive advantage dimensions. This dimension makes companies in the markets focus on reducing deadlines and shortening the time required to design new products and deliver them to customers. However, there are three aspects for delivery dimension related to time. These are (Krajewsky and Ritzman, 2005):

(1) Speed of delivery: this aspect is measured by the time it takes between receiving the customer's order and meeting it, which is called "waiting time". It is possible to increase the time spent in this aspect of delivery by reducing the waiting time. 
(2) Timely delivery: This means on-time delivery of customers' orders by the company.

(3) Speed of development: this aspect is measured by the time between developing new product's ideas and introducing product to the market.

There are many sources for achieving competitive advantage; three of them in most related literatures were identified as main sources. These sources were: innovation, knowledge and information, and time (Sachitra et al., 2016). They can enable company to create new ideas, generating creative practices, keeping abreast with the demands of modern technology, adapts and implements modern methods, having a speed in meeting the requirements and needs of customers and adapting to changing environment trends (Baroto et al., 2012).

\subsection{Strategic Management Accounting and Dimensions of Competitive Advantage}

Many authors from different research areas have highlighted the need for considering cross-level models when researchers analyze competitive advantage (see Daru, 2016). This way of analysis gives rich and valid explanation of the association between variables under study. Moreover, accounting functional level analysis is rarely used in analyzing the dimensions of competitive advantage. This limits our understanding how choices taken on this level influence a company's competitive position. In addition, the strategic issues of this functional level are also not addressed by previous work. As a result, no deeper understanding can be achieved about the impact of strategic management accounting on the dimensions of competitive advantage. Therefore the current study is an attempt to include this level of analysis in the research scope.

Theoretically, many authors have proposed a positive impact of strategic management accounting on the dimensions of competitive advantage (e.g.Chenhall and Langfield-Smith, 1998; Chiucchi, 2013; Cinquini and Tenucci, 2010; Hiller et al., 2014; Hilton, 2008; Kaplan and Norton, 1996; McManus, 2013; Nixon and Burns, 2012; Roslender and Hart, 2002). They claimed that strategic management accounting represent as a critical source of strategically orientated information for planning, decision making and control purposes that in turn influence the level of gaining competitive advantage. For example, Hilton (2008) claimed that strategic management accounting can help organization in achieving an appropriate and consistent alignment between management accounting and organization for strategic purposes in the first place, and bringing high possibilities to achieve the desired competitive advantages. He added that strategic management accounting represents as an essential practice that plays a significant role in identifying and evaluating the strategic competitive policies that result in achieving higher performance and competitive advantages. According to McManus (2013), in addition to have historical, financial, and internal information, achieving and sustaining competitive advantages requires external, non-financial, and future information. In the light of this argument, traditional management accounting (e.g. budgeting, costing and profitability analysis) is no longer an appropriate solution for achieving competitive advantages.

As mentioned earlier, strategic management accounting can play a significant role in providing information about markets, products, suppliers, competitors, and customers. This external orientation information represents a main source for analyzing competitive position of companies. Moreover, strategic management accounting also represents the key information provider of forward-looking information for strategic planning (Nixon and Burns, 2012). In addition, strategic management accounting can also provide internal orientation information regarding organizational resources and capabilities in order to support external competitive bases (Tayles et al., 2007). According to Agu et al. (2016), practicing management accounting from a strategic approach is essential in achieving sustainability of company in a competitive environment and having an efficient role in markets that in turn help in gaining a sustainable competitive advantage.

There are two complementary and mutually exclusive models for competitive advantage conceptualization. These models are the market-based model and the resource-based model (Ejrami et al., 2016). The market-based model includes cost variables, differentiation, efficiency, competitor evaluation, threats and risks analysis, etc. On the other hand, resource-based model is based on resources including all the resources owned by the company, whether physical or financial or human, to be moved and developed from within the company (Korankye, 2013). Accordingly, the two conceptualizations of competitive advantage have both external and internal orientation like strategic management accounting. Therefore, 
the present study proposes that strategic management accounting is likely associate with competitive advantage. That is, the information provided by strategic management accounting may play a significant role in achieving the dimensions of competitive advantages (i.e. cost, quality, flexibility and delivery). These four dimensions are seen to depend heavily on internal, external, financial, non-financial, historical, and prospective information (Ejrami et al., 2016; McManus, 2013) provided by strategic management accounting. On these grounds, the following study hypothesis is proposed:

H1: strategic management accounting is positively associated with the dimensions of competitive advantage.

This hypothesis is divided into the following sub-hypotheses:

H1-1: strategic management accounting is positively associated with the cost as a dimension of competitive advantage.

H1-2: strategic management accounting is positively associated with the quality as a dimension of competitive advantage.

H1-3: strategic management accounting is positively associated with the flexibility as a dimension of competitive advantage.

H1-4: strategic management accounting is positively associated with the delivery as a dimension of competitive advantage.

In assuming a contingency approach, the two dimensions of strategic management accounting will be deployed in a causal model as antecedents of competitive advantage's dimensions. The conceptual model of this study (see Figure 1) demonstrates that the four dimensions of competitive advantage are enhanced by the existence of the two dimensions of strategic management accounting.

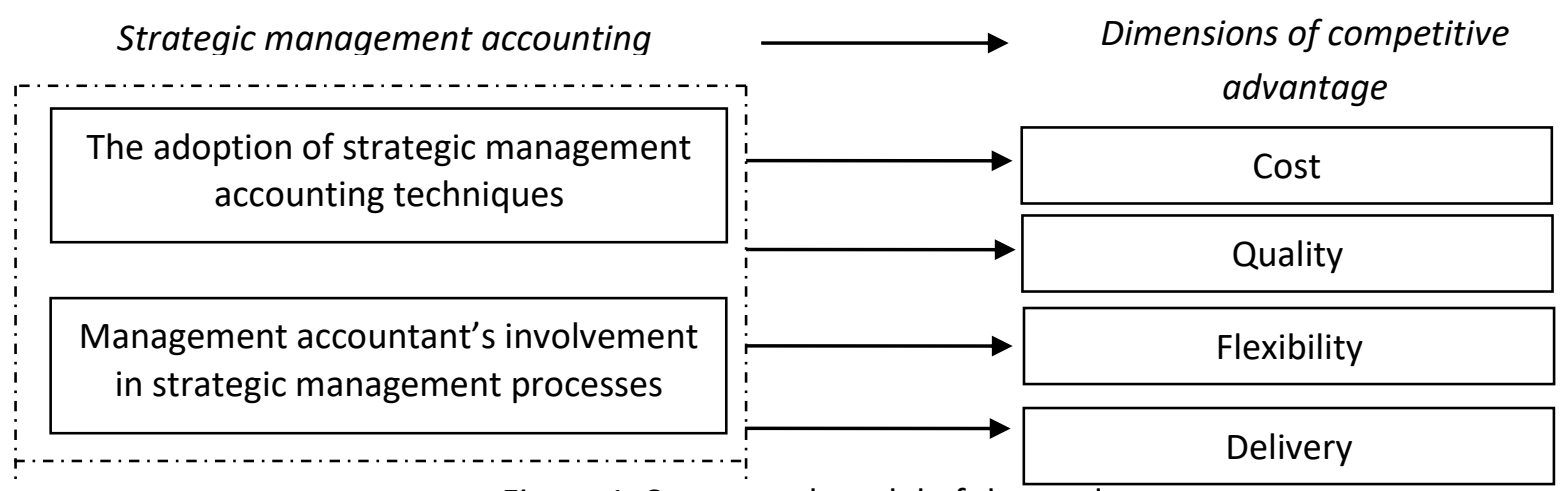

Figure 1. Conceptual model of the study

\section{Methodology of research}

\subsection{Sampling and Data Collection}

The study population consists of all industrial Saudi companies which are working at industrial cities in the capital of the Kingdom, Riyadh by the end of 2017. Three industrial cities are established in Riyadh and include 682 companies. However, the following companies will be excluded:

1. Companies which are encountered the case of shut down, liquidation, merge or acquisition.

2. Companies which have been conducted their operations less than five years ago.

3. Companies which do not have a specialized accounting department.

4. Companies which do not practice some strategic initiatives such as strategic management accounting techniques.

The researcher with the help of five academic staff contacted all companies identified as the study population by phone calls to identify those companies which meet the criteria set out in the study, and asks for their participation. Out of the total 308 companies from the first industrial city meet the selected criteria and 5 of them did not cooperate, so at the end (303) companies were investigated. No companies from the second and third industrial cities meet our criteria. For those who agreed to participate, the name and email of the management accountant and senior managers as two units of analysis were identified. As the selected companies are located in same location, the two surveys used were personally handed to all 
respondents ( $\mathrm{N}=303$ ). This was followed up with a phone call to get an appropriate response rate. After two months later, the researcher and his team made the final visit to collect the surveys. The response rate for the present study was actually striking; the researcher and his team enabled to collect 289 responses out of 303. Thus the response rate was $95.4 \%$. The study sample of management accountant consists of $68 \%$ male and $32 \%$ respondents with an average age of about 39.5 years. $88 \%$ are holding a bachelor degree or above, and have an average total experience in the accounting positions of about 13 years. On the other hand, the study sample of senior managers consists of $100 \%$ male respondents with an average age of about 45 years. $67 \%$ are holding a bachelor degree or above, and have an average total experience in their positions of about 18 years. In the light of Saudi industrial cities classification, 55\% of participated companies represent as large companies (employ more than 500 employees), and the rest of complies are classified as medium-sized companies with less than 500 employees. The average age of all companies participated in survey is about 27 years.

\subsection{Measures}

\subsubsection{Independent variables}

As mentioned before, prior work used two main dimensions to conceptualize and operationalize strategic management accounting (SMA). These are: (1) the adoption and use of strategic management accounting techniques (SMA1) and (2) management accountant's involvement in strategic management processes (SMA2). Accordingly, the adoption and use of strategic management accounting techniques was measured by using the five practices of strategic management accounting that are (1) Costing (e.g. activitybased costing, attribute costing, life cycle costing, quality costing, target costing, and value chain costing), (2) Planning, control, and performance measurement (e.g. benchmarking and balanced scorecard), (3) Strategic decision making (e.g. strategic costing, strategic pricing and brand valuation), (4) Competitor accounting (e.g. competitor cost assessment, competitor appraisal performance and competitive position monitoring), (5) Customer accounting (e.g. customer profitability/cost analysis, lifetime customer profitability analysis and valuation of customers as assets). Following the question "To what extent does your company use the following strategic management practices?", management accountants in the study sample responded on this question by identifying the level of practicing the 17 techniques of strategic management accounting on a five-point scale ranging from "1" (not at all), to " 5 " (to a great extent). The second dimension of strategic management accounting (SMA2) was measured using a reliable and validated instrument developed by Wooldridge and Floyd's (1990). This instrument includes five questions measuring the level of participation and involvement in the strategic management process. However, management accountants in the study sample responded to this instrument by evaluating their involvements into the strategic management process on a 5-point scale ranged from " 1 " (not at all involved) to " 5 " (fully involved). In sum, to measure the SMA variable, the researcher calculated the average response on the two dimensions of SMA that are SMA1 and SMA2.

\subsubsection{Dependent variables}

To measure the dimensions of competitive advantage, the researcher of the present study developed a measurement scale. This scale includes the four dimensions of competitive advantage identified previously in the literature review section in this study. These dimensions are: (1) Cost dimension (CA1) (2 items) (e.g. the ability of the company to compete against the major competitors based on low price), (2) Quality dimension (CA2) (2 items) (e.g. the ability of the company to deliver products that match the needs and desires of customers), (3) Flexibility dimension (CA3) (4 items) (e.g. the ability of the company to quickly produce a wide range of products as a response to customer needs), and (4) Delivery dimension (CA4) (3 items) (e.g. the ability of the company to make on-time delivery of customers' orders). Each dimension was measured by a set of items asking senior managers in the study sample to evaluate their companies in the light of these dimensions locally over the past five years. Likert scales ranging from 1, "very low" to 5, "very high." was used to identify senior managers' response. To evaluate the level of competitive advantage, the researcher the researcher was averaging the five dimensions of competitive advantage within one variable (CA). 


\subsubsection{Control variables}

To capture some variables that may have an impact on the independent variable and dependent variable and therefore influence the results of the regression analysis, the present study selected some related control variables mentioned on previous studies (e.g. Ah Lay and Jusoh, 2011; Cadez and Guilding, 2012; Hammad et al., 2010). These variables are: company age and company size (log of total employment).

\section{Results}

Table 1 provides the results of descriptive statistics, correlations, reliability and factor analyses for the study scales. In addition, Table 1 also provides the testing of sampling adequacy and the problem of multicollinearity by using Kaiser-Meyer-Olkin (KMO) and the variance inflation factor (VIF) tests respectively.

Table 1. Descriptive Statistics, Correlations, Reliability and Factor Analyses

\begin{tabular}{|c|c|c|c|c|c|c|c|}
\hline \multirow{2}{*}{ Item } & \multicolumn{2}{|c|}{ Factor Loadings } & \multirow[t]{2}{*}{ Communalities } & \multirow[t]{2}{*}{ Item-total Correlations } & \multirow{2}{*}{ Cronbach's Alpha } & \multirow{2}{*}{ Mean } & \multirow{2}{*}{ SD } \\
\hline & SMA & CA & & & & & \\
\hline SMA1 & 0.883 & & 0.766 & 0.752 & 0.94 & 3.06 & 1.362 \\
\hline SMA2 & 0.892 & & 0.689 & 0.624 & & 3.12 & 1.226 \\
\hline CA1 & & 0.802 & 0.669 & 0.666 & 0.91 & 3.11 & 1.111 \\
\hline CA2 & & 0.821 & 0.709 & 0.603 & & 3.25 & 1.089 \\
\hline CA3 & & 0.883 & 0.711 & 0.548 & & 3.09 & 1.208 \\
\hline CA4 & & 0.812 & 0.728 & 0.429 & & 3.01 & 1.302 \\
\hline VIF & 2.16 & 1.85 & & & & & \\
\hline $\mathrm{KMO}$ & & & & & & & \\
\hline
\end{tabular}

SMA = strategic management accounting; SMA1 = the level of adaption and use of strategic management accounting techniques; SMA2= the level of management accountant's involvement in strategic decision process; $C A=$ dimensions of competitive advantage; $C A 1=$ cost dimension; $C A 2=$ quality dimension; $C A 3=$ flexibility dimension; $C A 4=$ delivery dimension.

Table 1 show that the mean of practicing strategic management accounting techniques is 3.06 with a standard deviation of 1.362. This indicates that the level of adaption and use of strategic management accounting techniques by sample companies was at moderate level with a great variance in the level of adaption and use. In addition, the level of management accountant's involvement in strategic management processes was also at moderate level with a mean of 3.12 with a standard deviation of 1.226 indicating great variance between sample companies in the level of involvement. Dimension of competitive advantage scale shows mean values of 3.11 for cost dimension, 3.25 for quality dimension, 3.09 for flexibility dimension, and 3.01 for delivery dimension. These values indicate that sample companies achieve moderate level in each dimension of competitive advantage with quality dimension in the first rank and delivery dimension in the last rank. However, the high values of standard deviations for such dimensions indicate great variance in the level of achievement between sample companies.

From Table 1, the results of reliability test indicate that that the two scales of the present study have an acceptable level of internal reliability and consistency. The Cronbach's alpha for the strategic management accounting scale and the dimensions of competitive advantage are 0.94 and 0.91 respectively. In addition, all items have item-total correlation values greater than 0.5 , the acceptable limit by Nunnally (1978), therefore, no item has been dropped from the data. Furthermore, all factor loadings and communalities are above the acceptable limit of 0.50 suggested by Hair et al. (2009). As the value of $\mathrm{KMO}$ is 0.926 which is greater than 0.7, the minimum limit suggested by Hair et al. (2009), sampling adequacy is achieved. In addition, the values of variance inflation factor were less than 5 for both the study independent and dependent variables which in turn indicate an acceptable level (see Rogerson, 2001) and the absence of multicollinearity problem in the present study data. In sum, the above results indicate that the two scales used in the present study satisfy the reliability, internal consistency and construct validity. 
For the purpose of testing the main hypothesis $(\mathrm{H} 1)$, the current study used multiple regression analysis to test the association between the strategic management accounting and the dimensions of competitive advantage. Strategic management accounting is measured by averaging its two measurable dimensions that are SMA1 and SMA2, whereas, competitive advantage is measured by averaging its four measurable dimensions that are CA1, CA2, CA3, and CA4. Consequently, testing of hypothesis $\mathrm{H} 1$ is achieved through estimation of the following multiple regression model:

$C A=B_{0}+B_{1} S M A+B_{2} C S Z+B_{3} C A G+\varepsilon_{1}$

(model 1)

Where:

$C A$ represents the ability of company to achieve competitive advantages;

$S M A$ represents the level of practicing strategic management accounting;

CSZ represents the company size (log of total employment);

CAG represents the company age (in years);

$\varepsilon_{1}$ represents the unexplained error of the regression model.

Table 2. Regression Analysis Results-Model 1

\begin{tabular}{|c|c|c|c|c|c|c|c|c|c|}
\hline $\begin{array}{c}\text { Dependent } \\
\text { Variable }\end{array}$ & $\begin{array}{c}\text { Independent } \\
\text { Variable }\end{array}$ & $\begin{array}{c}\text { Coefficient } \\
\beta_{1} \\
\end{array}$ & $\begin{array}{c}\mathrm{t}- \\
\text { statistics }\end{array}$ & P-value & $\mathbf{R}^{2}$ & $\operatorname{adj} R^{2}$ & $\mathbf{F}$ & P-value & $\begin{array}{l}\text { Durbin } \\
\text { Watson }\end{array}$ \\
\hline \multirow[t]{3}{*}{$\mathrm{CA}$} & SMA & 0.532 & 14.63 & $0.002^{* *}$ & & & & & \\
\hline & CSZ & 0.203 & 1.36 & 0.625 & 0.362 & 0.317 & 128.69 & $0.003 * *$ & 2.36 \\
\hline & CAG & 0.169 & 3.26 & 0.403 & & & & & \\
\hline
\end{tabular}

Constant $\beta_{0}=5.23^{*}$

$* *$ significant at $\alpha \leq 0.01$

It is shown from Table 2 that practicing of strategic management accounting in terms of its two dimension (SMA1 and SMA2) has a significant and positive impact on the ability of the sample companies to achieve competitive advantage $(\beta=0.532, P<0.012)$. The $F$ value $(F=128.69,<0.003)$ is significant and indicates that the model 1 fits the data. In addition, Durbin Watson statistic value (2.36) indicates that there is no autocorrelation in the sample. The results also indicate that the size and the age of company as control variables have no significant impacts on the dimensions of competitive advantage. Furthermore, practicing of strategic management accounting accounts for $31.7 \%$ of the variation in the ability of company to achieve competitive advantages $\left(\operatorname{adj}^{2}=0.317\right)$. Thus, the main study hypothesis $(\mathrm{H} 1)$ that proposes a positive association between strategic management accounting and the dimensions of competitive advantage is statistically supported. This finding is consistent with the theoretical proposition identified by some authors in the field of strategic management accounting (e.g. Roslender and Hart, 2002; Cinquini and Tenucci, 2010; Chiucchi, 2013; Hiller et al., 2014; Chenhall and Langfield-Smith, 1998; Nixon and Burns, 2012; McManus, 2013; Hilton, 2008).

In order to test the study sub-hypotheses, regression analysis is also used to identify the association between strategic management accounting and the four dimensions of competitive advantage. Testing of these sub-hypotheses is achieved through estimation of the following regression models:

$$
\begin{aligned}
& C A 1=a_{0}+b_{4} S M A+b_{5} C S Z+b_{6} C A G+\varepsilon_{2} \\
& C A 2=b_{0}+b_{7} S M A+b_{8} C S Z+b_{9} C A G+\varepsilon_{3} \\
& C A 3=c_{0}+b_{10} S M A+b_{11} C S Z+b_{12} C A G+\varepsilon_{4} \\
& C A 4=d_{0}+b_{13} S M A+B_{14} C S Z+b_{15} C A G+\varepsilon_{5}
\end{aligned}
$$

Where:

CA1 represents the ability of company to achieve cost dimension; $C A 2$ represents the ability of company to achieve quality dimension; $C A 3$ represents the ability of company to achieve flexibility dimension; CA4 represents the ability of company to achieve delivery dimension; $S M A$ represents the level of practicing strategic management accounting; $\varepsilon$ represents the unexplained error of the regression model. 
Table 3. Regression Analysis Results-Model 2 to 4

\begin{tabular}{|c|c|c|c|c|c|c|c|c|c|}
\hline $\begin{array}{c}\text { Dependent } \\
\text { Variable }\end{array}$ & $\begin{array}{c}\text { Independent } \\
\text { Variable }^{1} \\
\end{array}$ & $\begin{array}{c}\text { Coefficient } \\
\beta_{i} \\
\end{array}$ & $\begin{array}{c}\mathrm{t}- \\
\text { statistics }\end{array}$ & P-value & $\mathbf{R}^{2}$ & $\operatorname{adj}^{2}$ & $\mathbf{F}$ & P-value & $\begin{array}{l}\text { Durbin } \\
\text { Watson }\end{array}$ \\
\hline CA1 & SMA & 0.405 & 8.88 & $0.011^{*}$ & 0.621 & 0.612 & 28.41 & $0.001^{* *}$ & 2.36 \\
\hline CA2 & SMA & 0.369 & 7.16 & $0.021^{*}$ & 0.607 & 0.533 & 20.22 & $0.019 * *$ & 1.98 \\
\hline CA3 & SMA & 0.301 & 8.12 & $0.016 *$ & 0.449 & 0.426 & 26.45 & $0.005^{* *}$ & 2.03 \\
\hline CA4 & SMA & 0.236 & 7.05 & $0.026^{*}$ & 0.167 & 0.111 & 16.12 & $0.034^{*}$ & 2.11 \\
\hline Constant & $a_{0}=1.02^{\prime}$ & $b_{0}=0$ & & $c_{0}=1.12^{*}$ & & $=1.09^{*}$ & & & \\
\hline
\end{tabular}

1 control variables are not included in table since they have no significant impact in the model.

$* *$ significant at $\alpha \leq 0.01$

*significant at $\alpha \leq 0.05$

The results in Table 3 show that practicing of strategic management accounting in terms of its two dimension (SMA1 and SMA2) has a significant and positive impact on the ability of the sample companies to achieve all dimensions of competitive advantage (i.e. cost, quality, flexibility, and delivery). All $\beta$ coefficients are significant and positive with the highest value for cost dimension $(\beta=0.405, P<0.011)$ and lowest value for delivery dimension $(\beta=0.236, P<0.026)$. The $F$ values presented in Table 3 are significant and indicate that the four models $(2,3,4,5)$ in the study fit the data, and the values of Durbin Watson statistic are in normal ranges. Moreover, practicing of strategic management accounting accounts for $61.2 \%$ of the variation in the ability of company to achieve cost dimension ( $\operatorname{adj}^{2}=0.612$ ), and accounts for $53.3 \%, 42.6 \%$, and $11.1 \%$ for the variation in the ability of company to achieve quality, flexibility and delivery dimension respectively. In general, the findings in Table 3 suggest that strategic management accounting is positively associated with the four dimensions of competitive advantage, thus supporting the four study sub-hypotheses H1-1, H1-2, H1-3, and H1-4.

\section{Discussions and Conclusions}

This study provides empirical evidence regarding the association between strategic management accounting and the dimensions of competitive advantage in Saudi industrial sector. Previous literature proposed that strategic management accounting may have an influential impact on competitive advantage (e.g. Roslender and Hart, 2002; Cinquini and Tenucci, 2010; Chiucchi, 2013; Hiller et al., 2014; Chenhall and Langfield-Smith, 1998; Kaplan and Norton, 1996; Nixon and Burns, 2012; McManus, 2013; Hilton, 2008), but empirical evidence is still scant. Therefore, the current study can be seen to break new ground in examining the association between strategic management accounting and competitive advantage. The results indicate that the strategic management accounting is significantly and positively related to the dimensions of competitive advantage collectively and individually. This positive impact on dimensions of competitive advantage is in line with the theoretical proposition identified in previous literature as mentioned above. Therefore, practicing management accounting from a strategic approach (the adoption and use of strategic management accounting techniques and involving management accountant in strategic management processes) enhances the company's ability in gaining competitive advantage. Typically, we can conclude that strategic management accounting is an antecedent of achieving competitive advantage. Accordingly, in order to achieve competitive advantage (s), industrial companies should try to adopt and use strategic management accounting techniques and involve their management accountants in the strategic management processes.

This positive association between strategic management accounting and the dimensions of competitive advantage is may be due to the nature of strategic management accounting. Strategic management accounting can provide decision maker in companies with strategically orientated information for planning, decision making and control that in turn influences the level of achieving competitive advantage (McManus, 2013), in addition strategic management accounting can help in identifying and evaluating the strategic competitive policies (Hilton, 2008). Furthermore, strategic management accounting information has external and forward-looking orientations. These orientations provide the strategic 
practice of management accounting an ability to provide crucial information about markets, products, suppliers, competitors, and customers with accurate information for anticipating future (Nixon and Burns, 2012). This information represents a core stone for enhancing company's ability to achieve competitive advantage. Moreover, strategic management accounting also represents the key information provider of internal information regarding the organizational resources and capabilities which in turn supports the external competitive base of companies (Tayles et al., 2007).

Furthermore, the positive association between strategic management accounting and competitive advantage can be explained by making a comparison between the nature of competitive advantage and the nature of strategic management. Competitive advantage has two complementary and mutually exclusive models: the market-based model and the resource-based model (Ejrami et al., 2016). The market-based model is oriented toward the external variables or factors in the surrounding environment (e.g. cost variables, differentiation, efficiency, competitor evaluation, threats and risks analysis etc.), where the resource-based model is oriented toward the internal resources and capabilities of the company (Korankye, 2013). Accordingly, competitive advantage has both external and internal orientation similar to strategic management accounting. Both competitive advantage models need adequate and relevant information as a means to achieve them, and the most relevant source for this information is likely to be strategic management accounting. This trend in practicing accounting management (i.e. strategic management accounting) has the ability to provide decision makers in company with the needed internal, external and future-oriented information for meaningful strategic decision making, consequently, managers will be able to make decisions that are more responsive to the rapid changes and uncertainties in business environment, and thus competitive advantage achievement will be improved (Alleyne and WeekesMarshall, 2011).

Surprisingly, the results of this study indicate that the impact of strategic management accounting is not limited to one dimension of competitive advantage but this impact covers all dimensions of competitive advantage. Cost, quality, flexibility, and delivery are influenced significantly and positively with practicing strategic management accounting in companies under consideration. According to Ejrami et al. (2016) and McManus (2013), these four dimensions of competitive advantage depend heavily on internal, external, financial, non-financial, historical, and prospective information. Again, strategic management accounting can provide these types of information which are needed to build such dimensions of competitive advantage.

As the present study provides new evidence to understand the effect of strategic management accounting on competitive advantage dimensions, drawing on data from Saudi industrial companies, it is important for industrial companies to adopt the strategic approach of management accounting to achieve competitive advantages, especially in terms of cost and quality. These two dimensions of competitive advantage are greatly influenced by strategic management accounting. In addition, it is found that the level of practicing management accounting from a strategic perspective is at moderate level in sample companies. As the results of the present study indicate that there is a positive association between strategic management and the dimensions of competitive advantage, those Saudi companies need to work hard to adopt the strategic approach of management accounting to enhance their competitive advantage. This importance of adoption increases if we know that Saudi industrial sector faces a set of challenges such as the need to improve the competitiveness of national products and keeping pace with developments in world markets (Saudi Industrial Development Fund, 2018). To adopt this approach, companies need to build an appropriate ground for practicing strategic management accounting by effective adoption and use of strategic management accounting techniques and involving management accountants in strategic decision making process. However, the later one requires that management accountants need to be "capable of interdisciplinary thinking and communication and able to understand the complex linkages and interrelationships inside the company"(Tillmann and Goddard, 2008).

The present study has some limitations and open areas for future research. Firstly, the present study limits itself to Saudi industrial companies listed in the industrial cities located in Riyadh. Caution is needed in case of generalizing the findings of this study especially outside Saudi Arabia because the general differences in internal or external environment between companies. In the same time, this offer an opportunity for future research to be carried out to generalize these findings or at least enabling for 
comparisons. Second, the present study evaluated competitive advantage that products hold locally, and it did not collect data on competitive advantage relative to imported products. Future research is needed to cover this limitation by measuring competitive advantage in relative to foreign products.

Finally, the present study has not investigated how some contingent factors such as environmental uncertainty, organizational strategies, competition intensity, and other factors influence the level of practicing strategic management accounting and achieving competitive advantage or affect the positive association between them. Future research may be carried out by taking into consideration these factors as controlling or moderating variables.

Acknowledgement: This project was supported by King Saud University, Deanship of Scientific Research, Community College Research Unit.

\section{References}

1. Agasisti, T., Arnaboldi, M., and Azzone, G. (2008). Strategic management accounting in universities: The Italian experience. Higher Education, 55, 1-15.

2. Agu, C. I., Nweze, A. U., Enekwe, C. I. (2016). The use of strategic management accounting techniques (SMATs) in sustainability performance measurement for corporate governance in Nigeria. International Journal of Academic Research in Accounting, Finance and Management Sciences, 6(3), 262271.

3. Ah Lay, T. and Jusoh, R. (2011). Business strategy, strategic role of accountant, strategic management accounting and their links to firm performance: an exploratory study of manufacturing companies in Malaysia. Proceeding in Accounting Research and Education Conference, University Teknologi MARA1-27.

4. Ahid, M. and Augustine, A. (2012). The impact of global financial crisis on Jordan. International Journal of Business and Management, 7(16), 80-88.

5. Aksoylu, S. and Aykan, E. (2013). Effects of strategic management accounting techniques on perceived performance of businesses. Journal of US-China Public Administration, 10(10), 1004-1017.

6. Al-khadash, H., and Feridun, M. (2006). Impact of strategic initiatives in management accounting on corporate financial performance: evidence from Amman stock exchange. Managing Global Transitions. 4(4), $299-313$.

7. Alleyne, P. and Weekes-Marshall, D. (2011). An exploratory study of management accounting practices in manufacturing companies in Barbados. International Journal of Business and Social Science, $9(2), 49-58$.

8. Andon, P., and Baxter, J. (2011). Introducing and contextualising customer lifetime valuation: A management accounting teaching resource. Accounting Education: An International Journal, 20, 39-61.

9. Anik, R., Nadjadji, A., and Suwignjo, P. (2010). Analysis of internal and external factors for competitive advantage of Indonesian contractors. Journal of Economics and Engineering, 2(4): 51-68.

10. Aver, B., Aaver, B. and Cadez, S. (2009). Management accountants' participation in strategic management processes: a cross industry comparison. Journal for East European Management Studies, 14 (3), 310-22.

11. Baroto, M.B., Abdullah, M.M.B., and Wan, H.L. (2012). Hybrid strategy: a new strategy for competitive advantage. International Journal of Business and Management, 7(20): 120-133.

12. Brem, A., Maier, M., and Wimschneider, C. (2016). Competitive advantage through innovation: the case of Nespresso. European Journal of Innovation Management, 19(1): 133-148.

13. Bromwich, M. (1990). The case for strategic management accounting: the role of accounting information for strategy in competitive markets. Accounting, Organization and Society. 15(1), 27-46.

14. Bromwich, M., and Bhimani, A. (1994). Management accountant pathways to progress. London,

15. Brouthers, K. D. and Roozen, F. A. (1999). Is it time to start thinking about strategic accounting? Long Range Planning, 32, 311-22.

16. Cadez S., and Guilding C. (2012). Strategy, strategic management accounting and performance: a configurational analysis. Industrial Management Data System, 112 (3), 484-501. 
17. Cadez, S. and Guilding, C. (2008). An exploratory investigation of an integrated contingency model of strategic management accounting. Accounting, Organizations and Society, 33 (7-8), 836-863.

18. Carlsson-Wall, M., Kraus, K., and Lind, J. (2015). Strategic management accounting in close interorganisational relationships. Accounting and Business Research, 45, 27-54.

19. Chen, Y., Hsu, J., Huang, M. and Yang, P. (2013). Quality, size, and performance of audit firms. The International Journal of Business and Finance Research, 7(5): 89-105.

20. Chenhall, R. H., and Langfield-Smith, K. (1998). The relationship between strategic priorities, management techniques and management accounting: an empirical investigation using a systems approach. Accounting, Organizations and Society, 23: 243-264.

21. Chiucchi, M. S. (2013). Intellectual capital accounting in action: enhancing learning through interventionist research, Journal of Intellectual Capital, 14, 48-68.

22. Cinquini, L., and Tenucci, A. (2010). Strategic management accounting and business strategy: A loose coupling?. Journal of Accounting and Organizational Change, 6, 228-259.

23. Combe, A. (2012). Marketing and flexibility: debates past, present and future. European Journal of Marketing, 46, 1257-1267.

24. Cuganesan, S., Dunford, R., and Palmer, I. (2012). Strategic management accounting and strategy practices within a public sector agency. Management Accounting Research, 23, 245-260.

25. Daniel I.m Prajogo, C., and Peggy McDermott, (2011). Examining competitive priorities and competitive advantage in service organisations using Importance-Performance Analysis matrix. Managing Service Quality: An International Journal, 21(5), 465-483.

26. Daru, M. (2016). Total Quality Management (TQM): a strategy for competitive advantage. International Journal of Research in IT and Management (IJRIM), 6(9): 51-55.

27. Diab, S. M. (2014). Using the competitive dimensions to achieve competitive advantage: A study on Jordanian private hospitals. International Journal of Academic Research in Business and Social Sciences, $4(9), 138-150$

28. Diab, S. M. (2014). Using the competitive dimensions to achieve competitive advantage: A study on Jordanian private hospitals. International Journal of Academic Research in Business and Social Sciences, 4(9), 138-150.

29. Dunk, A. S. (2011). Product innovation, budgetary control, and the financial performance of firms. The British Accounting Review, 43 (2), 102-111.

30. Ejrami, M., Salehi, N., and Ahmadian, S. (2016). The effect of marketing capabilities on competitive advantage and performance with moderating role of risk management in importation companies. Procedia Economics and Finance, 36: 22-28.

31. Eryesil, K., Esmen, O., and Beduk, A. (2015). The role of strategic flexibility for achieving sustainable competition advantage and its effect on business performance. World Academy of Science, Engineering and Technology, 9(10), 587-593.

32. Ewert, R., and Ernst, C. (1999). Target costing, co-ordination and strategic cost management. European Accounting Review, 8, 23-49.

33. Fauré, B. and Rouleau, L. (2011). The strategic competence of accountants and middle managers in budget making, Accounting, Organizations and Society, 36, 167-182.

34. Hammad, S. A., Jusoh, R. and Yeen Nee Oon, E. (2010). Management accounting system for hospitals: a research framework. Industrial Management Data System, 110(5), 762-84.

35. Hammad, S.A., Jusoh, R. and Yeen Nee Oon, E. (2010). Management accounting system for hospitals: a research framework. Industrial Management Data System, 110, 762-84.

36. Hiller, K., Mahlendorf, M. D., and Weber, J. (2014). Management accountants' occupational prestige within the company: A social identity theory perspective. European Accounting Review, 23, 671691.

37. Hilton, R. W. (2008). Managerial accounting. ( $7^{\text {th }}$ edition), New York: McGraw-Hill.

38. Hoque, Z. (2001) Strategic Management Accounting: Concepts, Processes and Issues, Oxford: Chandos Publishing. 
39. Jack, L. (2009). The Adoption of Strategic Management Accounting Tools In Agriculture Post Subsidy Reform: A Comparative Study of Practices in the UK, the US, Australia and New Zealand. Research executive summaries series, Essex Business School, University of Essex. 5(7), 1-7.

40. Johnson, H. T., and Kaplan, R. S. (1987). Relevance lost: the rise and fall of management accounting. Harvard Business School Press, Cambridge, MA.

41. Kaplan, R. S. and Norton, D. P. (1996). Using the balanced scorecard as a strategic management system. Harvard Business Review, 74, 75-85.

42. Kaplan, R.S., and Norton, D.P. (2001). Transforming the balanced scorecard form performance measurement to strategic management: Part I. Accounting Horizons, 15, 87-104.

43. Kırlı, M. and Gümüş, H. (2011). The implementation of strategic management accounting based on value chain analysis: value chain accounting. International Journal of Social Sciences and Humanity Studies. 3(1), 307-321.

44. Korankye, A. (2013). Total Quality Management (TQM): a source of competitive advantage. a comparative study of manufacturing and service firms in Ghana. International Journal of Asian Social Science, 3(6): 1293-1305.

45. Kotler, P. (1997). Marketing management: Analysis, planning, implementation, and control $\left(9^{\text {th }}\right.$ ed.). Englewood Cliffs, NJ: Prentice-Hall.

46. Krajewski, L. J., and Ritzman, Larry, P. (2005). Operations Management. $7^{\text {th }}$ ed, Prentice Hall: New Jersey.

47. Lambert, C., and Pezet, E. (2011). The making of the management accountant - Becoming the producer of truthful knowledge. Accounting, Organizations and Society, 36, 10-30.

48. Langfield-Smith, K. (2008). Strategic management accounting: How far have we come in 25 years?. Accounting, Auditing \& Accountability Journal, 21, 204-228.

49. Ma, Y., and Tayles, M. (2009). On the emergence of strategic management accounting: An institutional perspective. Accounting and Business Research, 39, 473-495.

50. McManus, L. (2013). Customer accounting and marketing performance measures in the hotel industry: Evidence from Australia. International Journal of Hospitality Management, 33, 140-152.

51. McManus, L., and Guilding, C. (2008). Exploring the potential of customer accounting: A synthesis of the accounting and marketing literatures. Journal of Marketing Management, 24, 771-795.

52. Mia, L., and Clarke, B. (1999). Market competition, management accounting systems and business unit performance. Management Accounting Research, 10 (2), 137-158.

53. Mishra, R .N., and Mishra, C. (2010). Relevance information literacy in digital environment. Journal of Emerging Trends In Computing and Information Sciences, 1(1), 48-54.

54. Naliaka, V.W., and Namusonge, G.S. (2015). Role of inventory management on competitive advantage among manufacturing firms in Kenya: a case study of UNGA Group Limited. International Journal of Academic Research in Business and Social Sciences, 5(5): 87-104.

55. Nixon, B. and Burns, J. (2012), The paradox of strategic management accounting. Management Accounting Research. 23(4), 229-244.

56. Noordin, R., Zainuddin, Y., Fuad., Mail, R. and Sariman, K. (2015). Performance outcomes of strategic management accounting information usage in Malaysia: insights from electrical and electronics companies. International accounting and business conference, IABC 2015, Available online at www.sciencedirect.com.

57. Nunnally, J. C. (1978). Psychometric theory, (2 ${ }^{\text {nd }}$ ed.). New York: McGraw-Hill.

58. Oboh, C. and Ajibolade, S. (2017). Strategic management accounting and decision making: A survey of the Nigerian Banks. Future Business Journal, 3 (2), 119-137.

59. Porter, M. E. (1985). The Competitive Advantage: Creating and Sustaining Superior Performance. NY: Free Press, 1985.

60. Ranjith, V. (2016). Business Models and Competitive Advantage. Procedia Economics and Finance, 37: 203-207.

61. Rogerson, P. A. (2001). Statistical methods for geography. London: Sage. 
62. Roslender, R. and Hart, S. (2002). Integrating management accounting and marketing in the pursuit of competitive advantage: the case for strategic management accounting. Critical Perspectives on Accounting, 13 (2), 255-277.

63. Roslender, R. and Hart, S. J. (2003). In search of strategic management accounting: theoretical and field study perspectives, Management Accounting Research, 14, 255-279.

64. Roslender, R., and Hart, S.J. (2010). Taking the customer into account: Transcending the construction of the customer through the promotion of self-accounting. Critical Perspectives on Accounting, $21,739-753$.

65. Sachitra, V., Chong, S.C., and Khin, A.A. (2016). Sources of competitive advantage measurement in the minor export Crop Sector in Sri Lanka result from pilot study. Asian Journal of Agricultural Extension, Economics \& Sociology, 12(2): 1-15.

66. Saudi Industrial Development Fund (2018). Available online at https://www.sidf.gov.sa/en/Pages $\angle$ default.aspx

67. Shah, H., Malik, A., and Malik, M. S. (2011). Strategic Management Accounting: A Messiah for Management Accounting. Australian Journal of Business and Management Research, 1(4), 1-7.

68. Siegel, G., and Sorensen, J. E. (1999). Counting More, Counting Less: Transformations in the Management Accounting Profession, the 1999 Practice Analysis of Management Accounting. USA: Institute of Management Accountants.

69. Sigalas Ch., Economou V.P., Georgopoulos N.B. (2013). Developing a measure of competitive advantage. Journal of Strategy and Management, 6(4), 320-342.

70. Simmonds, K. (1981). Strategic management accounting, Management Accounting, 59 No. 4, $20-$ 29.

71. Soltani, S., Nayebzadeh, S., Moeinaddin, M. (2014). The impact examination of the techniques of management accounting on the performance of tile companies of Yazd. International Journal of Academic Research in Accounting, Finance and Management Sciences, 4(1), 382-389.

72. Tayles, M., Pike, R.H., and Sofian, S. (2007). Intellectual capital, management accounting practices and corporate performance: Perceptions of managers. Accounting, Auditing \& Accountability Journal, 20, 522-548.

73. Tillmann, K., and Goddard, A. (2008). Strategic management accounting and sense-making in a multinational company. Management Accounting Research, 19, 80-102.

74. Wang, W.C., Lin, C.H., and Chu, Y.C. (2011). Types of competitive advantage and analysis. International Journal of Business and Management, 6(5): 100-104.

75. Ware, E. (2014). Investigate the benefit practice of total quality management as competitive advantage in corporate institution: a case study of Cocoa-Cola bottling company Ghana Ltd. Research Journal of Finance and Accounting, 5(23): 97-99.

76. Weinstein, A. (2012). Superior customer value: strategies for winning and retaining customers. $3^{\text {rd }}$ ed. Boca Raton, Florida: CRC Press-Taylor \& Francis Group.

77. Wooldridge, B., and Floyd, S. W. (1990). The strategy process, middle management involvement, and organizational performance. Strategic Management Journal, 11(3), 231-241. 